\title{
W. Domeris
}

\section{MEEK OR OPPRESSED? READING MATTHEW 5:5 IN CONTEXT}

\begin{abstract}
According to the Gospel of Matthew 5:5, Jesus pronounces a blessing on "the meek"

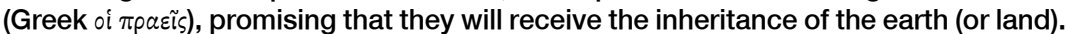
The words of Jesus are a quotation from the LXX of Psalm 37:11 and each of the Hebrew terms (subject, object and verb) need careful consideration. Following, the Hebrew original we might translate the verse in Psalm 37:11 as "The oppressed/ humiliated will take possession of the land". The force of the original saying finds its meaning in the wider context of the Psalm, where wealthy landowners threaten the interests of ordinary peasants and they cry out to God for justice.
\end{abstract}

The variance between the Hebrew (MT) and the Greek (LXX) raises anew the interpretation of these words of Jesus. Who did Matthew's Jesus have in mind - the meek of emerging Christianity or the poor and humiliated peasants, who made up the majority of his Palestinian audience? In this article, I consider the implications of Jesus addressing a peasant audience in a conversation about taking possession of farming land and then extend this discussion into the emerging peasant realities of the post-revolutionary context in Galilee and Judaea. In the light of the present archaeological data, and the rabbinic sources, peasant life continued more or less unchanged with little indication of large-scale estates.

\section{LOST IN TRANSLATION}

The association of the meek with the inheritance of the earth is so much a part of the traditional reading of Matthew 5:5 that it has become the de facto key for virtually every sermon (ancient and modern) preached on that text. In the process, I believe, the wider implications of Jesus' words to the common people of Galilee and Judaea have been lost. The third beatitude is a quotation from one of the great Psalms of encouragement,

Dr. W. (Bill) Domeris, South African Theological Seminary \& Research Fellow, Faculty of Theology, University of the Free State, Bloemfontein. E-mail: wdomeris@gmail.com 
in the face of evil and oppression (Psalm 37:11). The Greek (LXX), compromised the sense of hope for the poor and oppressed inherent in the original Psalm, and this was then lost in the subsequent translations. The shout of the Psalm for justice and land became instead a whisper of an anomalous interchange.

As the metaphorical reading of the poor and oppressed, in later times, gained hold, the result was an increased reluctance on the part of translators to grapple with the reality of poor peasants taking possession of the land. Consequently, the inheriting meek of the LXX was preferred to the original Hebrew (MT), and the majority of the English translations of Psalm 37:11 now speak about the meek, the humble or the gentle, who will inherit the earth, and very few render the Hebrew literally. Given the negative connotations of meek as passive submissiveness in modern English, this is a problem. The proverbial tail has been allowed to wag the dog. Some linguistic archaeology is needed, both for Psalm 37:11 and for Matthew 5:5 and that is the intention of this article.

\section{SHADOW SIDE OF LIFE}

Psalm 37 is one of several Psalms, which speak about the poor and oppressed in a way that makes poverty, something more than an economic problem. This is in line with modern studies of poverty (Øyen, Miller and Samad 1996). Samad writes,

\footnotetext{
Poverty is neither an economic nor a purely social problem, but is multifaceted, with economic, social, political, cultural and demographic dimensions. It is a condition as well as a process ..., a cause as well as an effect (1996:34).
}

Similarly, Soares-Prabhu reminds us that in the Biblical mindset, "poverty is a social idea and not just an economic category" (1991:156). The poor are "a sociological group rather than a religious group" and "may be defined not by their spiritual attitude of dependence on God but by their sociological situation of powerlessness and need ... not necessarily economic need" (Soares-Prabhu 1991:156-57). The poor themselves are not a homogeneous group, experiencing a varied degree of power and powerlessness, shame and honour, temporary poverty and extremes of poverty (Domeris 2007:9-26, 169-178).

The Hebrew Bible devotes a considerable amount of space to descriptions of the poor, sometimes in polemical sermons against the rich and powerful (like Amos 2:6-8; 8:4-6), and, at other times, reminding the reader of the needs of widows and orphans (Deut. 24:17-19; 
cf. Baker 2009:189-198). However, without a doubt one of the classic descriptions of the poor in Israel comes from the book of Job:

Like wild donkeys in the desert, the poor go about their labour of foraging food; the wasteland provides food for their children. They gather fodder in the fields and glean in the vineyards of the wicked. Lacking clothes, they spend the night naked; they have nothing to cover themselves in the cold. They are drenched by mountain rains and hug the rocks for lack of shelter (Job 24:5-8; Translation by Pope 1965:161).

Job continues, in his description, by pointing out the unfair nature of the social and economic situation, hinting at an abusive and unequal reality, and raising hard questions about the justice of God:

The fatherless child is snatched from the breast; the infant of the poor is seized for a debt. Lacking clothes, they go about naked; they carry the sheaves but still go hungry. They crush the olives among the terraces; they tread the winepresses, yet suffer thirst. The groans of the dying rise from the city, the souls of the wounded cry out for help. But God charges no one with wrongdoing (Job 24:8-12; Translation by Pope 1965:161).

Job has described what modern sociologists term "the social construction of poverty" (Øyen, Miller and Samad 1996; Øyen 1997). The category of "the poor" is socially constructed and socially maintained, at least in part, by those who are not poor. Øyen distinguishes between the internal forces, which serve to create and to sustain poverty and the forces external to the poor, which serve to work against any escape, on their part, from the clutches of poverty (1997:127).

Multiple Hebrew words exist in the domain of poverty (cf. Pleins 1992; Hartin 2000; Domeris 2007:14-26) and describe in subtly varied ways the shape of a now dimly discerned reality. We no longer have the proper means to distinguish fully between the various shades of meaning, of even the most common words. How does one separate the peasant poor (דלל II see Carroll 1997) from the needy (אֶביון see Domeris 1997a) or the oppressed (for example, ינה see Swart 1997; דכא see Domeris 1997b), leaving aside the other categories, including the puzzling עַנַ II? Like Paul gazing into "a glass, darkly" (1 Cor. 13:12), we try to make sense of the relics, which the waves of history has deposited on the shores of time.

When the Greeks and then the Romans occupied the land of Judaea, they brought a new vocabulary of poverty - a new set of labels, for the enduring poor. In contrast to the rich variety of the Hebrew, the New Testament makes use of only three terms ( $\pi \varepsilon v \eta \varsigma, \pi \tau \omega \chi o ́ s$, and $\pi \varepsilon v i \chi p o ́ s)$ with 
senses ranging from poor, through needy to destitute (2 Cor. 9:9; Mk. 10:21 and Matt. 5:3; Lk. 21:2). One thing, however, remained unchanged, namely Øyen's (1997:127) external and internal forces of poverty, framing the economic and social world of Jesus (Schottroff \& Stegemann 1986; Moxnes 1988; Hamel 1989: Oakman 2012).

\section{THE POINT OF DEPARTURE: PSALM 37:11}

Psalm 37, as its opening line exclaims, is about the threat of the wicked and the emotions that they evoke: "Do not become upset [or angry] about the wicked, or envious of those who work unrighteousness" (Ps. 37:1). Violence is endemic: "The wicked have drawn out the sword, and have bent their bow; to cast down the poor and needy; to slay such as are upright in the way" (Ps. 37:14); and again, "The wicked watch the righteous, and seek to kill them" (v. 32). The Psalm juxtaposes the wicked (from the Heb. root רשע; verses 1, 10,12 and so on), who from the context appear to be wealthy landowners (see vv. 16, 35) over against several other entities, including, those who hope in the Lord (v. 9); the oppressed/humbled (v. 11); the righteous (9 times: vv. 12, 16a, 17b, 21b, 25b, 29, 30a, 32 and 39a); the poor and needy (v. 14b); those whose ways are upright (v. 14c); the blameless (vv. 18a, 37a); those the Lord blesses (v. 22a); the just (v. 28); the upright (v. 37a), and finally the person of peace (v. 37b). There is a strong sense of the interplay between insider (righteous, poor) and outsider (wicked), which is best understood in the context of an anti-society with its attendant anti-language (see Malina and Rohrbaugh 1998:46-47).

The Psalmist, through skilful use of anti-language, offers a credible alternative to despair and frustration in a world, where the wicked appear to be invincible - namely, the hope for the true justice of God. This same sentiment recurs throughout the Psalm (vv. 7, 9, 10, 12-17, 20-22, 28, $34-37,40)$, with the repeated assurance of the demise of the wicked (vv. 2, $9,10,22,38) ;$ they and their descendants will be cut off from the land (v. 28), and their power will be broken (vv. 15, 17) through the judgement of God (Ps. 37:13,20).

Looking specifically at Psalm 37:11, it becomes obvious that the various English translations paint a diverse, if confusing, picture, as the following examples show: "But the meek shall inherit the earth; and shall delight themselves in the abundance of peace" (KJV and ASV); or "But the humble will possess the land and enjoy prosperity and peace" (TEV); or "But the meek will inherit the land, and enjoy great peace" (NIV); or my personal favourites "But the poor will take the land and enjoy a big harvest" (CEV) and "Down-to-earth people will move in and take over, relishing a huge bonanza" (The Message). 
The literal Hebrew of Psalm 37:11a announces "But the oppressed/ humbled will take possession/inherit [the] land"; in parallel with (v. 11b) "and they will enjoy great peace". Each word, especially the first half of the verse, calls out for particular attention, namely, the subject (עָנָנוּים)

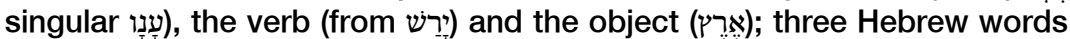
side by side - but each capable of several meanings and so the history of interpretation has been an interesting road.

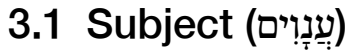

The adjective עָנָנ Should be related to the Hebrew form ענה (Wegner 1997:449), which with its cognate roots, has as its basic meaning "the use of force leading to humiliation" (Dumbrell 1997:454; cf. Gerstenberger 2001:231-2). The following examples indicate the range of possible translations, from a very meek or perhaps a very distressed Moses (Num. 12:3) to a meek or perhaps a poor king (Zech. 9:9) who rides in triumph, on a donkey like his ancestor David did. In their respective discussions of this semantic field, Gerstenberger (for TDOT) and Dumbrell (for NIDOTTE) come to strikingly different conclusions, not about the root meaning of the term or its original intention (the poor and oppressed of Israel) but its extended meaning - what I term the "metaphorical meaning".

Dumbrell (1997) begins with the original negative meanings found in the Hebrew root, but then writes with particular reference to Psalm 37 about a change of meaning:

It can thus be argued that 'ānāw and probably 'ānî have changed their meaning from a depiction of material disadvantage and the humiliation that follows, to a self-chosen title of people who in their deep need and difficulty turn to Yahweh and find help from him. Doubtless poverty and disadvantage had functioned as fruitful soil for piety and humility ... By praising God they will experience an inner control over external circumstance. They are heirs to the promises given to Israel. Theirs is the earth. They are the true Israel (1997:461).

In spite of Dumbrell's promising start, his switch to the metaphorical reading of the Hebrew Psalm wrests it from its historical context and endows it, instead, with an otherworldly connotation. Somehow the real poor and humiliated appear to have been lost in his desire to produce a reading where the non-poor will feel comfortable. To suggest that poverty or oppression is "fruitful soil for piety and humility" (1997:461) is rather like telling an abused woman that her husband's violence is good for her development of piety and humility. This is not to say that all the poor of Psalm 37 are righteous, or all the wealthy, evil - but in the insider-speak of the Psalmist, the mention of land (in v. 11) stands as a banner of hope, 
and if we discard this, the Psalm loses much of its power and promise. Gutierrez (1973:289-90) cautions against any such tendency to spiritualise poverty, so as to make reading the Bible a more comfortable exercise for the non-poor.

Gerstenberger (2001) offers a reading which, I believe, is closer to the original meaning of the Hebrew root ענה:

The words associated with the root 'ana Il belong to a negatively charged domain of knowledge and experience ... The nouns and adjectives refer to situations inimical to human life. The basic experience appears to be "affliction" in its various forms (2001:234).

Thus the semantic context of our lexical group reflects fear and a sense of impending death ... Together with many other lexical groups of similar content, this group arises from the darkness of human experience, the shadow side of life (2001:235).

Gerstenberger's expression "the shadow side of life" is a useful one, for understanding the category of those described as and airmly dispenses with the idea that it leans towards some spiritual application. He writes,

In the differentstreams of OT traditionaboutthe "poor, lowly, oppressed," various nuances of our lexical family evolve in various places. Included are texts referring to the psychic and personal qualities, characteristics, and attitudes. But there is no observable "development" in the direction of spiritualization (2001:252 my emphasis).

Psalm 37 is a hymn in praise of the God of justice, who, unlike the deity in Job 24:12, is prepared to act on behalf of those who have been wronged. But the Psalmist offers more - the promise of land, real farming land, and crops that feed hungry children. To stop short of this promise, is to strip this Psalm of its contextual reality and ultimately its physical hope for the future.

\subsection{The verb (ירָש}

The normal verb for inherit is from the Hebrew root נחל, but here in Psalm 37:11, we have the verb ירָׁ which means "to possess", "to occupy", "to forcibly dispossess" and by extension "to inherit" (Wright 1997:547-8; Lohfink 1990:368-9). Wright (1997:547) sees the primary meaning of the verb as "to take or gain possession of" (ירָ I qal) and "to drive out, destroy, dispossess" (in the hiphal). The verb, for example, is found on the Moabite Stone, where King Mesha reports that "Omri took possession of all the land of Madeba" (KAl 181:7; cf. Lohfink 1990:377). The primary context is the inheritance or possession of land (Lohfink 1990:382-8), as in Ahab's 
possession of Naboth's vineyard (1 Kings 20:15-19), or the peaceful resettlement in Judaea after the exile (Ezr. 9:11 and Jer. 30:3). However, as Wright (1997:548) and Lohfink (1990:383-390) show, the root's essential connection is with the conquest narratives, especially in Deuteronomy (Deut. 11:23f; cf. Deut 2:12, 21, 22; 9:1; 30:5).

Lohfink, with particular reference to Psalm 37:11, argues that "the most common meaning is probably acquisition through right of conquest after a battle or war" (Deut. 33:23; Jer. 8:10) and concludes that "It conjures up images of powerful people dispossessing the poor, yet in this Psalm, it is the poor and the righteous who dispossess others and occupy their land" (1990:371-2). The retention of this paradox is critical to the correct interpretation of the Psalm. Lohfink quite correctly adds, "It is possible that the psalm refers specifically to the peasantry, who faced increasing class differences and were in danger of losing their land to great landowners" (1990:394).

Wright, by contrast, takes the meaning of the verse into the eschatological dimension and concludes "The moral and spiritual flavour of the words is again to the fore, but in eschatological terms that anticipate the beatitude based on 37:11 (Matt 5.5)". How quickly the genuine hopes of the peasantry for food and land, morph into the religion of the non-poor.

\subsection{The object (ארץ)}

The noun אר is capable of various shades of meaning ranging from the earth of Genesis 1 to the very precise sense, still present in Modern Hebrew, of the land of Israel (Ottosson 1974). When used with the definite article and no further detail, the most common meaning, by far, is the Promised Land, which would lead the reader of this Psalm to see a connection with the original possession of the land by the Children of Israel, as described in the books of Joshua and Deuteronomy (Ottosson 1974:401-5). According to Psalm 37, the poor and righteous, like their ancestors, are in line to possess their share in the Promised Land and consequently to experience abundant prosperity (Lohfink 1990:394). In the context of Psalm 37, this is accompanied by God's judgement on the wicked - they and their descendants will be cut off from the land.

In this connection, I am reminded, both, of the re-allocation of the land by Nebuchadnezzar, during the opening years of the Exile, when the land of the wealthy was distributed to the poorest of the poor (2 Kings 25:12) and of the reaction from the elite in exile (Ezek. 11:15). Such elite concerns might easily have led to the poor, of passages like Psalm 37:11, being replaced by the inheriting meek as happened in the LXX. Such replacement 
theology, where the original poor are replaced by the non-poor of later times, is precisely what Gutierrez (1973:289-90) was warning against.

\subsection{The muddied waters: The Septuagint reading (Psalm 36:11)}

The LXX renders the inheriting poor of Psalm 37[36]:11, as "the humble"

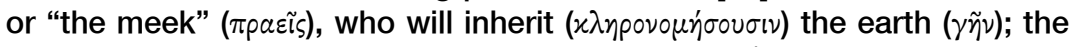

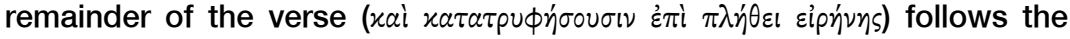
literal Hebrew. This translation, while understandable, fundamentally alters the meaning of the Hebrew.

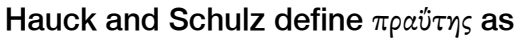

... mild gentle friendliness [which] is the opposite of roughness and bad temper. It is fitting to show mildness to one's own people and harshness to enemies. But the gentleness should not lead to selfabasement (Dio C 43:3,6 and 74:5,7) (Hauck \& Schulz 1968:646).

The Greek world was shaped by notable values like shame and honour, and by the avoidance of hubris, or arrogance towards the gods. Meekness or gentleness (in opposition to anger) is in essence the avoidance of hubris while still seeking out those things which lead to honour: an active attitude rather than a passive stance.

In the LXX, the adjective $\pi p a \tilde{s} \varsigma$ is found 16 times in all, but the diversity of Hebrew terms it translates is rather wide. For example, it renders עָנִני (7 times, for example, Ps. 24:9), עָנָנ (5 times, for example, Zech. 9:9) and עַנָָָָ (4 times, for example, Ps. 44:5; Hauck \& Schulz 1968:647). The feminine noun teaîtins is found 10 times: 4 times in the Psalms, each time for a different Hebrew word (for example, Ps 44[45]:5); once in the extended Greek text of Esther (5:1); and 5 times in the Apocrypha with the sense of gentleness (for example, Sir 1:27; Hauck \& Schulz 1968:647). The widely diverse choice of Hebrew words rendered by $\pi \rho a \tilde{s} s$ and $\pi \rho a \tilde{\tau} \tau \varsigma$ is described by Hauck and Schulz, (1968:647) as "capricious". There is simply no logic evident here, even if we take account of class-interests playing a role.

The Septuagint use of the verb "inherit" ( $\chi \lambda \eta$ роvо $\mu \varepsilon^{\prime} \omega$ or the more emphatic

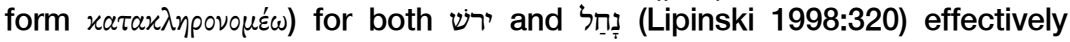
eliminated the basic differences between the Hebrew words terms. As a result the line between ordinary inheritance on the family front, the sacred inheritance of the Promised Land, and land acquired by strength of arms, was dissolved (Foerster 1965:769). Furthermore, with this shift in the understanding of inheritance, we find that in place of the literal rendering of the Hebrew (Ps. 37:11 - the humbled or humiliated poor taking possession 
of the land of Israel), we have a translation which leans towards a more metaphorical interpretation.

\section{WE-THE POOR: THE USE OF עִגָנוּים AS A SELF-DESIGNATION}

From time to time, the Hebrew Bible applies terms drawn from the literal world of the poor to the non-poor - either individually or corporately (Isa. 14:32; 26:1-6; 61:1-7; Zeph. 2:3; Ps. 72:2). When taken out of their insider-outsider context (Stulman 1995), such terms may appear as the signs of a form of spiritualisation of poverty - but they are not. The writers do not believe that they are poor or needy, either spiritually or physically. They are using the terms as a self-description, as a metaphor, a label, for their own identity, to connect them with the older Biblical traditions, and especially the oft-repeated assertion of God's preferential treatment of the poor and the righteous (for example, Ps. 72:1-4). Terms, like "the poor" or "the needy", formed a vehicle of association for the insider language of religious communities who found themselves in tension with the wider community (Halliday 1976).

For insiders, like the Qumran community, Psalm 37 provided a rich metaphorical source (Pesher reading) for their own self-definition and purposes $\left(4 \mathrm{Qp}{ }^{37}\right)$. They readily identified with the poor, oppressed and righteous of this Psalm and the promised occupation of the land (1QM). Various words for the literal poor of the Hebrew Bible resurface in their own hymns, but used metaphorically (1QH 2:13, 32, 34; 3:25; 5:13-22; $1 Q M$ 11:9; cf. Gerstenberger 2001:252). In this way, the writers of the scrolls were able to connect with the traditions of Israel implicit in their chosen texts. In time, the Christians would do the same. The logic was not to belittle the poor, or to reduce the reality of their plight, but rather to forge a connection with the poor of Biblical tradition, who were often equated with the righteous (as here in Psalm 37). This is not a spiritualisation of poverty, as some have maintained, but the use of a profoundly powerful metaphor in the context of anti-language.

\section{THE SENSE OF PARADOX AND THE BEATITUDES}

The essence of the Beatitudes is the sense of paradox. Remove that sense, and one has lost the essential meaning of these blessings. For example, there is no merit in mourning or being persecuted. Those who are pure in heart (Matt. 5:8) are implicitly compared with those who emphasise outward purity at the cost of inner holiness (Matt. 23:27). Those who 
hunger and thirst for justice (or righteousness; Matt. 5:6) with those whose desires are limited to physical needs, including wealth (Matt. 6:24. Those who are poor in spirit (Matt. 5:3) are not those "who know that they are spiritually poor" (TEV) but those whose poverty has robbed them of spirit, meaning their self-esteem (Davies \& Allison 1988:442-445; Borg 2006:190). To be poor in spirit is not a good thing - it is a desperate strait as the following examples, drawn from the Hebrew Bible make clear (Isa. 57:15ff; Prov. 16:9; cf. also 1 Sam. 1:15; Ps. 34:18; Isa. 54:6).

Spectral shadows, in the background to the teaching of Jesus, were "Political Oppression, Economic Exploitation and Religious Legitimation" (Borg \& Crossan 2008:71-72). Oakman elaborates

The political aims of Jesus were deeply influenced by a concern about agrarian taxation leveraged by commerce, and the social situation developing in Herodian Galilee around the turn of the eras, and must, rather, be seen within this maelstrom of social change and distorted traditional peasant values (Oakman 2012:43).

The classical reading of the Sermon on the Mount remains that of Betz, edited by Collins (1995), who like some writers (for example, Lapide 1986; Davies \& Allison 1988; Schnackenburg 2002; Evans 2012) immediately saw the connection with the peasant poor of Jesus' time (Betz \& Collins 1995:126-130). For Borg (2006:189-90) those addressed, including the meek and poor in spirit, form one group, who with the literal poor, are those who are oppressed, mourn the deaths of loved ones and are last in line to inherit the land.

Hendrickx (1986:15) writes,

Jesus addresses people who are poor, who mourn, and who hunger and thirst. These are in fact variations of one and the same theme. These beatitudes deal with people who in one way or another live in a miserable situation. They are called blessed, not because of their virtue, their internal disposition, their openness to the kingdom of God, but simply because they are poor and as such benefit from God's disposition towards them.

Among such people, there are those who long for land, basic farming land that can feed them and their families.

\subsection{The right to land (Matthew 5:5)}

In the third beatitude (Matt. 5:5), having spoken about the poor, stripped of spirit (Domeris 1987:32-34), and those who mourn, following the violence endemic in Palestine (Horsley 1987: Horsley 1995; Oakman 2012), Jesus goes on to speak about the right to the land. The adjective tpaîs is used 
four times in the New Testament (Matt. 5:5, 11:29; 21:5 and 1 Pet. 3:4). On two occasions, in Matthew, it renders a quotation from the LXX. The same Hebrew term עָנָ underlies both verses (Ps. 37:11 in Matt. 5:5; Zech. 9:9 in Matt. 21:5), but to what extent we can carry forward these Hebraic notions is open to debate. Perhaps, in view of the suggested audience of Jesus (Echegaray 1984:84-5; Hendrickx 1986:15; Evans 2012:106; Borg \&

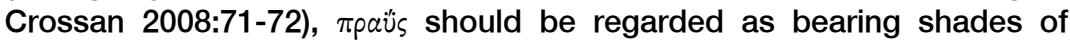
meanings ranging from "humble" to "oppressed", such as might be relevant to a peasant community in Galilee or Judaea in the first century. In

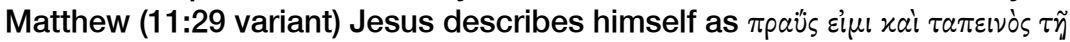
xapdia and so, I believe, aligns himself with the poor and oppressed of the Beatitudes, through the anticipation of his own humiliation and oppression. I do not think that meekness with its implicit sense of passivity and failure to stand up for one's rights suits Matthew's Sermon on the Mount (cf. Matt. 5:38-42; cf. see Domeris 1987:47-51).

Hauck and Schulz (1968:649) believe that the $\pi$ paĩ are "the oppressed" who have lost their land. They add a qualification

... who acknowledge not their own will but the great and gracious will of God. To them Jesus promises the inheritance of the coming aeon, which includes (cf. Mt 19:29) secure dwelling in their own land (Hauck \& Schulz 1968:649).

With a stronger emphasis on a "this-worldly" solution, Borg argues that Jesus was preparing his audience for the paradoxical upside-down values of the Reign of God, which were destined to replace the existing political hierarchy (2006:189-190). Accordingly, Jesus promised his peasant audience that in God's Kingdom, those oppressed and spiritually stripped of self-worth would join hands with other oppressed people to take centre stage in the new Promised Land. The Exodus theme returns to the strains of Jubilee. Lapide writes,

The courage Jesus inspires here in his followers is an essential prerequisite for his program of action which follows, for unless power is awarded to the powerless, hope to the despairing, and light to those who live on the shadow side of life, no effective collaboration in the saving of the world can be expected (Lapide 1986:27).

Evans concludes,

Jesus in the Third Beatitude then speaks to Israel's hope for national renewal, which includes, in this instance, regaining the land itself ... Jesus' beatitude and its allusion to the promised re-inheriting of the land would strike a hopeful chord in the hearts of his hearers (Evans 2012:106). 
In the tension between "this-worldly inheritance" of Evans (2012:106) and the "otherworldly inheritance" of Hauck and Schulz, we have the modern exegetical challenge of Matthew 5:5.

\section{AGAINST ALL ODDS: PEASANT SURVIVAL}

To speak about Jesus pointing to the inheritance of the land of Israel by the poor and oppressed, begs the question of the history of the land. What happened to the peasantry of Judaea and Galilee, especially in the post-70 CE period? Who ultimately inherited the land? To answer these questions, we need to consider both the literary evidence and the evidence of archaeology (and there has been much of the latter in recent decades) in the regions of Judaea and Galilee.

Against the odds, the peasants of both Judaea and Galilee survived the double onslaught of the Romans (70 CE and 135 CE; Freyne 2000:123; Safrai 1994). Peasants remained the vast majority of the population (over 90 percent according to Sartre 2005:217). Peasant diversity apparently increased, for in speaking, specifically of the agrarian workers, of this later time, the Talmud uses five different Aramaic terms, depending on the financial arrangements. These arrangements ranged from various rental forms (fixed rentals of up to $50 \%$ of the harvest), to a fixed payment for preparing land for farming, and finally to the ordinary day-labourers (Satre 2005:157-160). Daily life, in general, continued as before, and the rabbinic sources (Buchler 1912; Alon 1989) are replete with the necessary detail of Jewish peasant existence, including markets, weddings, land gifts, taxes and trades, both for Judaea and Galilee.

\subsection{Peasant poor in Judaea (post 70 CE)}

Josephus, writing about the consequences of the first Jewish revolt(Josephus War 7, 216) makes mention of an edict of the emperor (Vespasian) delivered in the months following the resolution of the First Revolt (c. $70 \mathrm{AD}$ ), to the Legate of Syrian (Lucilius Bassus) and the Procurator of Palestine (Laberius Maximus) to the effect that all (emphatic $-\pi \tilde{\alpha} \sigma \alpha \nu)$ the land $(\gamma \tilde{\eta} \nu)$ of Judah (the

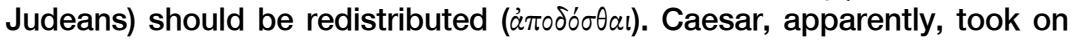
the role as imperial landowner and some $\mathbf{8 0 0}$ soldiers were rewarded for their effort with land in the vicinity of Emmaus. The impression is that the land was farmed as an imperial estate.

Satre (2005:208) responds,

However, this is probably not accurate, for most of the lands were sold or given to partisans, and we have proof that there was a 
good deal of property in private hands (following Isaac 1984:44-50;

Safrai 1994:324).

Josephus mentions Jews being settled in Jamnia and Lydda in 68 CE by Vespasian (War 4, 8, 1). Josephus himself received property from Titus (Life 76). Buchler, on the basis of an extensive survey of the Jewish sources, concludes that provided someone was willing to pay the taxes, the Romans were not particularly concerned about who actually did the farming. However, they did keep a tight control on the registration of property (1912 n.p.).

The Talmudic sources point to fairly substantial communities living in Jamnia (for example, BT. Rosh Hashanah 31b) and Lydda with mention of some substantial land-holdings, both imperial (JT. Ta'an., IV, 69a, 18; Mekhil., 19, 1, p. 61b) and private. R. Johanan b Zakkai established a school in Jamnia (Gittin, 56b), while R. Eliezer had a school of his own in Lydda (BT. Sanhedrin 32b). In the case of those Jews who defected to the Romans, we know that they were treated reasonably well, especially those of the ruling class who arrived with gifts (Josephus War 6.2.2; 6.8.3). The poor also survived (Tosefta, 'Arakh. 4, 27 and Pe'ah 2. 21; Berakhot, 28 a; Nedarim 9. 10). R. Akiba was once asked by the Roman governor why God did not take care of the poor in Israel if he loved them (Bava Batra, $10 \mathrm{a}$ ). Perhaps this was in response to the lean times which immediately followed the Great Revolt. Caring for the poor continued and we read that during the time of Rabbi Akiba, Rabbi Jesheb'ab gave away all his property to the poor - one clear instance of the poor receiving land. He was rebuked by Akiba who told him that the rabbis approved of giving away only 20 percent of one's land to the poor (J.T. Pe'ah, I, 15 b, 39).

Schwartz, on the basis of archaeological work, refers to the extensive destruction meted out by the Romans, following the Great Revolt (2014:238-252). Clearly agriculture suffered in the immediate aftermath, Jewish land was confiscated and given to Roman veterans or supporters, or even deserters. But on the other hand, it is clear that several Jewish landowners were able to remain on their lands but it is not clear whether this was "as owners, sharecroppers or tenant farmers" (Schwartz 2014:245).

Archaeology supports the idea that recovery in Judaea was rapid in the toparchies of Acraba, Gophna, Herodian, Jericho and Beit Netopha (Schwartz 2014:245). This was also true generally in the Shefela and perhaps even in the environs of Jerusalem following some newly discovered papyri related to Jewish life between the two revolts (Schwartz 2014:246-8). Rabbinic sources comment that the land in Judaea following the Revolt, continued to be fertile, even more so than in Galilee (Bava Batra, 122a; Ketubot, 112a). 


\subsection{The peasant poor in Galilee (post $70 \mathrm{CE}$ )}

Safrai (2014:278-312) discusses the socio-economic and cultural developments in the Galilee from the late first century into the early third century (CE). He begins by referring to the severe destruction of Galilean towns in the Great Revolt (Gamla, Yodafat, Khirbet Betiha and Magdala) which were left in ruins (2014:279). Josephus (Vita 235) made mention of some 204 cities, towns and villages in Galilee in the years before the Revolt, and that seems to have been possible (Ben David 2011). With reference to the much debated issue of imperial or royal landed estates (see Chancey \& Porter 2001:194; Fiensy 2012), Safrai speaks of the search for Romanstyle villas, where so far archaeology has failed to find indications in terms of marble work, mural friezes and mosaics (2014:298-9), or even pagan temples (2014:302;) until the later centuries.

In terms of large estate buildings, following Roman lines, the only examples found so far are in the fringes of Galilee, including near Mount Carmel (Safrai 2014:304) at Ramat Ha-Nadiv, and another estate building at Horvath Zur and in the immediate environs of Caesarea (Hirschfeld \& Birger-Calderone 1991). Beit Shearim was by far the largest village in Galilee, adjacent to an estate of Agrippa II (or Bernice his wife) and was surrounded by what seem to be hamlets and estates farmed by "independent tenant farmers" (Safrai 2014:306). It seems that in places where the population were willing to acquiesce to Roman power, the people continued their lives and occupations, but under the burden of new Roman taxes and the ever present reality of Roman troops billeted in Galilean cities (Chancey \& Porter 2001:193).

Generally, social stratification in Galilee was not as sharp as in other parts of the Roman Empire - and there seems (following Anderson 1998) to be evidence of a reasonable level of prosperity across the villages of Galilee in the second century BC and following. Archaeology bears witness to an increased numbers of villages, perhaps the result of a mass migration from Judaea during the period of the revolt and its immediate aftermath (Anderson 1998:464-5). Public squares, housing public buildings including a substantial synagogue, became normative for the rural villages of Galilee, with small, but individualistic houses on streets and alleys radiating out from this central square (Hirschfeld 1995; Anderson 1998:461-2).

\section{A LAST WORD}

What is there in the third Beatitude which stirs our hearts and brings us hope? How different is that hope from the hope of that original audience of Jesus' time or the older audience of Psalm 37:11? Have we somehow 
lost the sole passage where Jesus spoke of the restitution of farming land? Having written this article, my hope is that the reader will now pause and wonder whether there were indeed peasants who heard in these words an answer to their cry "How long, O God, must we wait?"

\section{BIBLIOGRAPHY}

ALON, G.

1989. The Jews in their land in the Talmudic Age (70-640 CE). London: Harvard University Press.

ANDERSON, J.D.

1998. The impact of Rome on the periphery: The case of Palestina - Roman period (63 BCE - 324 CE). In: T.E. Levy (ed.), The archaeology of society in the Holy Land (London/Washington: Leicester University Press), pp. 446-469.

BAKER, D.L.

2009. Tight fists or open hands? Wealth and poverty in Old Testament Law. Grand Rapids: Eerdmans.

Ben David, C.

2011. Were there 204 settlements in Galilee at the time of Josephus Flavius? JJS LXII(1):21-36. http://dx.doi.org/10.18647/3006/JJS-2011

BetZ, H.D. \& Coluins, A.Y. 1995. The Sermon on the Mount: A commentary on the Sermon on the Mount, including the Sermon on the Plain (Matt 5:3-7:27 and Luke 6:20-49). Minneapolis: Fortress.

BORG, M.J.

2006. Jesus: Uncovering the life, teachings, and relevance of a religious revolutionary. New York: Harper Collins.

BorG, M.J. \& Crossan, J.D.

2008. The last week. What the Gospels really teach about Jesus' final days in Jerusalem. London: SPCK.

BUCHLER, A.

1912. The economic condition of Judaea after the destruction of the Second Temple. Jews College, London, publication no. 4. [Online.] Retrieved from: http://www.adath-shalom.ca/buchler.htm [2015, 5 Jan].

CARRoll, M.D.

1997. \#19 דלל NIDOTTE I:951-954.

Chancey, M.A. \& Porter, A.

2001. The archaeology of Roman Palestine. Near Eastern Archaeology 64(4):164-203. http://dx.doi.org/10.2307/3210829 
Davies, W.D. \& Allison, D.C.

1988. Matthew 1-7: Vol I. New York: T \& T Clark. ICC.

DoMERIS, W.R.

1987. Portraits of Jesus - Matthew: A contextual approach to Bible study. London: Collins.

1997a. \#36 אֶבְיוֹ NIDOTTE I:228-232.

1997b. \#1917 דכא NIDOTTE I:943-46.

2007. Touching the heart of God: The social construction of poverty among Bible peasants. New York/London: T \& T Clark. LHBOTS 466.

DUMBRELL, W.J.

1997. \#6705 עָנָ NIDOTTE 3:454-464.

EChegaray, $\mathrm{H}$.

1984. The practice of Jesus. Maryknoll. Orbis.

Evans, C.A.

2012. Matthew. New York: Cambridge University Press. NCB. http://dx.doi. org/10.1017/CBO9781139045858

FIENSY, D.

2012. Did large estates exist in Lower Galilee in the first half of the first century CE? Journal for the Study of the Historical Jesus 10:133-153. http://dx.doi. org/10.1163/174551912X640212

FoERSTER, W.

1965. $x \lambda \tilde{n}$ pos. TDNT 3:758-769, 776-785.

FREYNE, S.

2000. The Galilean world of Jesus. In: P.F. Esler (ed.), The early Christian world (Vol 1-11) (Oxford: Routledge), pp. 113-135.

Gerstenberger, E.

2001. עָנזָה II. TDOT XI:230-252.

GutierRez, G.

1973. A theology of liberation: History, politics and salvation. Maryknoll: Orbis.

HALLIDAY, M.A.K.

1976. Anti-languages. American anthropologist (New Series) 78(3):570-584. http://dx.doi.org/10.1525/aa.1976.78.3.02a00050

Hamel, G.

1989. Poverty and charity in Roman Palestine: First three centuries CE. Berkeley: University of California Press. NES 23.

HARTIN, P.J.

2000. Poor. In: D.N. Freedman (ed.), Eerdmans Dictionary of the Bible (Grand Rapids: Eerdmans), pp. 1070-1071. 
HAUCK, F. \& SchulZ, S.

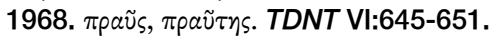

HENDRICKX, H.

1986. The Sermon on the Mount. Maryknoll: Orbis.

HIRSCHFELD, Y.

1995. The Palestininian dwelling in the Roman-Byzantine Period. Jerusalem: Israel Exploration Society.

HiRschfeld, Y. \& Birger-Calderone, R.

1991. Early Roman and Byzantine estates near Caesarea. IEJ 41:87-111.

HORSLEY, R.A.

1987. Jesus and the spiral of violence: Popular Jewish resistance in Roman Palestine. San Francisco: Harper and Row.

1995. Galilee. History, politics, people. Valley Forge: Trinity.

IsAAC, B.E.

1984. Judaea after AD 70. JJS 35:44-50. http://dx.doi.org/10.18647/1121/ JJS-1984

LAPIDE, P.

1986. The Sermon on the Mount: Utopia or prgram for action? Maryknoll: Orbis.

LIPINSKI, E.

1998. נָחד TDOT IX:319-335.

LOHFINK, N.

1990. ירירש TDOT Vl:368-396.

MaCPHerson, S. \& Silburn, R.

1998. The meaning and measuring of poverty. In: S. MacPherson \& R. Silburn (eds.), Poverty: A persistant global reality (London: Routledge), pp. 1-19.

Malina, B.J. \& Rohrbaugh, R.L.

1998. Social-Science commentary on the Gospel of John. Minneapolis: Augsburg Fortress.

MOXNES, $\mathrm{H}$.

1988. The economy of the Kingdom: Social conflict and economic relations in Luke's Gospel. Philadelphia: Fortress.

OAKMAN, D.E.

2012. The political aims of Jesus. Minneapolis: Fortress.

OtTosson, M.

1974. ארק TDOT I:388-405.

Øyen, E., Miller, S.M. \& SAmad, S.A. (Eds.)

1996. Poverty: A global review. Handbook on international poverty research.

Oslo: Scandanavian University Press. 
ØYEN, E.

1997. The act of building bridges between the world of the poor and the world of the non-poor. In: Atal, Y. \& Øyen, E. (eds.), Poverty and participation in civil society. Proceedings of a UNESCO/CROP round table (Delhi: Abhinav), pp.123-142.

Pleins, J.D.

1992. Poor, poverty. $A B D$ 5:402-14.

POPE, M.

1965. Job. New York: Doubleday AB 15.

SAFRAI, Z.

1994. The economy of Roman Palestine. London and New York: Routledge. http://dx.doi.org/10.4324/9780203204863

2014. Socio-economic and cultural development in the Galilee from the late first to the early third century CE. In: P. J. Tomson \& J. J. Schwartz (eds.), Jews and Christians in the first and second centuries: How to write their history (Leiden: Brill), pp. 278-312.

SAMAD, S.A.

1996. The present situation in poverty research. In: E. Øyen, S.M. Miller \& S.A. Samad (eds.), Poverty: A global review, Handbook on international poverty research (Oslo: Scandanavian University Press), pp. 33-46.

SARTRE, M.

2005. The Middle East under Rome. Cambridge, MA: Harvard University Press.

SCHNACKENBURG, $R$.

2002. The Gospel of Matthew. Grand Rapids: Eerdmans.

Schottroff, L. \& Stegemann, W.

1986. Jesus and the hope of the poor. Maryknoll: Orbis.

SchWARTZ, J.J.

2014. Yavne Revisited: Jewish 'survival' in the wake of the War of Destruction. In P. J. Tomson \& J. J. Schwartze (eds.), Jews and Christians in the first and second centuries: How to write their history (Leiden: Brill), pp. 238-252.

SoARes-Prabhu, G.M.

1991. Class in the Bible: The Biblical poor a social class? In: R.S. Sugirtharajah (ed.), Voices from the margins: Interpreting the Bible in the Third World (Maryknoll: Orbis), pp. 141-171.

Stulman, L.

1995. Insiders and outsiders in the Book of Jeremiah: Shifts in symbolic arrangement. JSOT 66:65-85. http://dx.doi.org/10.1177/030908929502006604

SWART, I.

1997. \#3561 ינה NIDOTTE 2:471-2. 
VAn Gemeren, W.A. (Ed.) 1997. Dictionary of the Old Testament Theology and Exegesis (5 Vols). Carlisle: Paternoster.

Wegner, P. 1997. \#6700 ענה NIDOTTE 3: 449-452.

WRIGHT, C.J.H. 1997. \#3769 ירש NIDOTTE 2:547-49.

Keywords

Matthew 5:5

Meek

Ps. 37:11

Oppressed

Possession of land
Trefwoorde

Matteus 5:5

Sagmoediges

Ps 37:11

Onderdruktes

Grondbesit 